\title{
SLO VS INVERSE VELOCITY METHOD: A STUDY TO EXAMINE EFFECTIVE APPROACH TO PREDICT SLOPE FAILURE
}

\author{
Maria Christine Rosaria, Rania Salsabila, Muhammad Khalif Arda, Fery Andika Cahyo and \\ Rachmat Hamid Musa
}

Geotechnical Support Service, GroundProbe Indonesia

\begin{abstract}
Provided with accurate and quasi real time deformation data, there are at least 2 methods that can be utilized to predict a slope failure. Inverse velocity method, coined by Fukuzono, aims at the interception of inverse velocity line to zero value at $X$ time axis as the prediction of slope failure. More recent method called SLO, develop by Mufundirwa, puts emphasize on interception of acceleration regression line with $X$ velocity axis. This paper is intended first and foremost to establish well-structured comparison between the two aforementioned methods. By using the same set of displacement data that show progressive deformation trend from Slope Stability radar, both $S L O$ \& Inverse Velocity method will be put into trial. Not only the accuracy of the failure prediction time, but also the comparison between the $R^{2}$ attribute will be examine to reveal which method that yield better data statistically. One of the selected study case, from several which is presented on the paper, reveal that SLO method give failure prediction closer with the actual failure compared to Inverse Velocity method. The actual failure is happening at 21:59 AM January $I^{\text {st }}$ 2016. SLO method generates failure prediction 10 minutes prior the actual failure, while Inverse Velocity generates failure prediction plus 68 minutes after the failure. $R^{2}$ value for SLO method and Inverse Velocity method respectively are $0.710 \& 0.630$. Apart from this results comparison, a more in depth examination toward the nature of both methods delivers pro \& con of each method. SLO method seems more accurate but having a constraint in which if there are no previous database of maximum velocity during collapse, prediction is almost impossible to make. Inverse Velocity method could address this flaw by projecting the inverse velocity line to zero value for the very least. Further explanation about the flaw and advantages of both methods will be conveyed in more detail on the later part of this paper.
\end{abstract}

Key words: Failure Prediction, SLO, Inverse Velocity, SSR

\begin{abstract}
ABSTRAK
Dengan adanya pengambilan data deformasi yang akurat dan mendekati "real time", terdapat setidaknya dua metode yang dapat digunakan untuk memprediksi longsor. Metode inverse velocity, yang dikembangkan oleh Fukuzono, adalah metode yang menggunakan perpotongan grafik inverse velocity dengan titik nol sebagai acuan atau nilai dari prediksi longsor. Metode lain yang lebih baru dibandingkan metode inverse velocity adalah metode SLO yang dikembangkan oleh Mufundirwa. Metode ini lebih ditekankan pada perpotongan antara grafik akselerasi dengan nilai kecepatan pada sumbu X. Tujuan utama dari paper ini adalah penyajian perbandingan yang terstruktur antara kedua metode tersebut. Penelitian terhadap metode SLO dan inverse velocity menggunakan data deformasi progresif yang sama dari Slope Stability Radar. Tidak hanya keakuratan prediksi waktu longsor, tetapi perbandingan nilai $\mathrm{R}^{2}$ pun akan menentukan metode yang lebih efektif secara statistik. Pada salah satu studi kasus, dari beberapa kasus yang dibahas di paper ini, menunjukkan bahwa metode SLO memberikan prediksi waktu longsor yang lebih mendekati waktu longsor yang sebenarnya jika dibandingkan dengan metode inverse velocity. Longsor yang sebenarnya terjadi pada tanggal 1 Januari 2016, pukul 21:59. Metode SLO menghasilkan prediksi longsor 10 menit lebih awal dari waktu longsor yang sebenarnya, dimana metode inverse menghasilkan prediksi longsor 68 menit setelah waktu longsor. Nilai $\mathrm{R}^{2}$ untuk metode SLO dan inverse velocity adalah
\end{abstract}


0.71 dan 0.63. Di samping perbandingan kedua hasil di atas, pemahaman lebih mendalam tentang sumber dari kedua metode tersebut memunculkan hasil plus dan minus dari masing-masing metode. Metode SLO memang terlihat lebih akurat namun metode ini membutuhkan data kecepatan maksimal saat kejadian longsor sebelumnya. Jika tidak ada, maka prediksi hampir tidak mungkin untuk dibuat. Sebaliknya, kelemahan tersebut tidak terdapat pada metode inverse velocity karena dapat diproyeksikan pada titik nol. Penjelasan lebih dalam mengenai kelebihan dan kekurangan dari kedua metode tersebut akan dibahas selanjutnya pada paper ini.

Kata kunci: Prediksi longsor, SLO, Inverse velocity, SSR

\section{A. INTRODUCTION}

The capability to predict slope failure in mining area, is an imperative method to address and manage slope instability related hazard. Slope instability hazard in the form of mine wall collapse is still proved to be one of the most severe events that could harm not only the mining equipment but also took life casualty as well in many cases. A data provided by Indonesia Rock Mechanic Society reveals that from 2012 to 2016, accident related with slope failure or collapse are taking account $43 \%, 16 \%, 36 \%, 30 \%$ and $17 \%$ of total accident in both open pit and underground mining in Indonesia respectively (Gunarto, 2017). Provided that mine-site endowed with sophisticated monitoring tools, such as slope stability radar, that will enable a closed spaced deformation data acquisition, progressive trend could be easily detected. Progressive trend is the first and foremost tell tale of an impending slope failure. The definition of progressive itself is a state of slope movement in which acceleration has took place. Both the SLO \& Inverse method that will act as the backbone of this paper to predict failure, required progressive deformation trend as the prerequisite.

The importance to attain a fairly accurate prediction has never been more prominent especially in the current day and age, in which technology has been relied upon more aggressively to pursue greater margin of profit. Slope stability radar thus has been utilised not only to fulfil its conventional role, that is to monitor slope deformation behaviour, but also to augment the effort to do production optimization. It becomes more prevalent nowadays for mining company to work in highly unstable area, which based on conventional slope stability analysis are no longer workable, with the assist of slope stability radar. When the site engineer is bestowed with critical and opportune information such as failure prediction time, one would be able to manage the severity of geotechnical hazard better and at the same time improving the retrieval rate of ore or commodity from highly delicate area. Failure prediction thus at the very least has to satisfy 2 tenets. First the prediction yielded by any method applied on the data from slope stability radar will be perceived as good, as long as it registered before the actual failure. Second, the prediction must be able to be generated relatively in a quick fashion, thus give enough time for site engineer to elaborate measure to address the impending failure.

This paper will delve into a study towards 2 failure prediction methods, Inverse velocity \& SLO, within the framework of 2 tenets that will satisfy the requirement of good failure prediction mention on previous paragraph. Inverse velocity method was developed by Fukuzono in 1985 to predict slope failure based on inverse velocity value. The method is taking advantage on the nature inverse velocity chart that will depict a downward linear trend towards zero when a slope is about to experiencing failure. Thus progressive deformation trend is represented by this downward linear trend in inverse velocity value, and failure prediction is generated by projecting this downward line to certain value closed to zero. While SLO method, developed by Mufundirwa (2008), is utilizing an acceleration chart resulted by the multiplication of velocity and time accumulation. Progressive trend thus will be represented by an upward linear trend on acceleration chart. Failure prediction in turns could be generated by projecting this upward linear acceleration chart toward certain value based on velocity of previous failure case in the area where monitoring has been done. The 
comparison of both method, from the point of view of the statistical attribute and head to head accuracy comparison against the actual failure time, will be further scrutinized and digest to find which method that proved to be the most favourable one.

\section{B. METHODOLOGY}

Research conducted within orderly structure and systematic approach will yield clear framework for achieving research objectives. In general, the research stages are shown in the flowchart below.

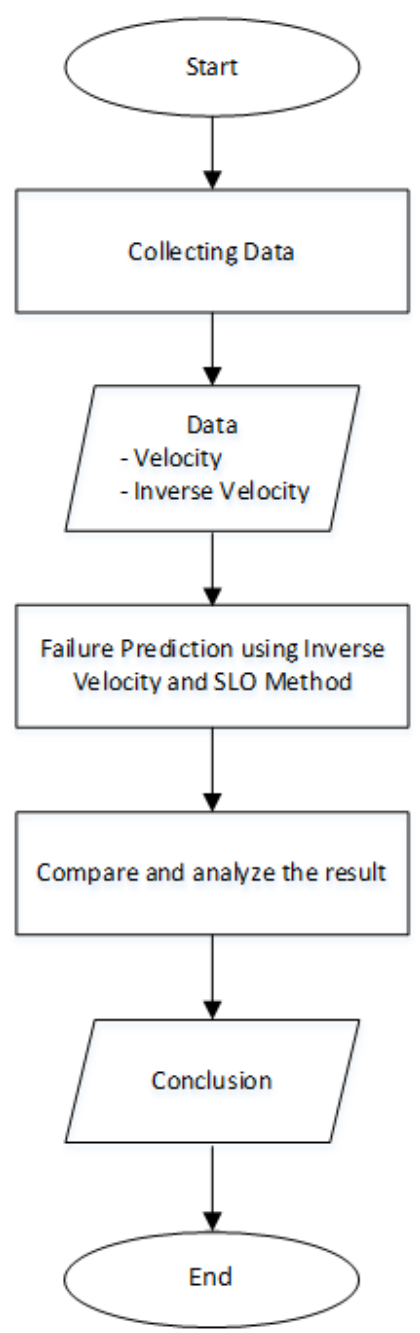

Figure 1. Methodology step

1. Collecting data

Primary data, such as inverse velocity and velocity from failure event, are obtained from SSRViewer software's velocity tabulation. Those failure data are exported to excel spreadsheet. In this research, there are eight failure events data which are used in this study.

2. Failure prediction time

After exporting data to excel, the first step is calculating time per scan. Time per scan is required to calculate time accumulation. Then, time accumulation is calculated by adding time per scan from the earlier scan to the next scan until the last scan data. To generate failure prediction using SLO method, one of essential attribute is acceleration which is obtained from 
velocity multiply by time accumulation. General equation of SLO developed by Mufundirwa was being used as the basic of the life expectancy of the slope wall as shown as below:

$$
t \frac{d u}{d t}=T f \frac{d u}{d t}-B
$$

Then, from those data, SLO chart can be generated with velocity (in VCP 60 minutes) as X axis and acceleration as $\mathrm{Y}$ axis. From this chart, the equation and chi square $\left(\mathrm{R}^{2}\right)$ value can be generated. Chart equation contains $y$ as acceleration value and $x$ as assumed velocity value which obtained from previous failure event with an assumption that failure in the same system and area will represent similar behaviours, included its velocity. Failure prediction time is obtained from chart equation from SLO chart as seen on image below.

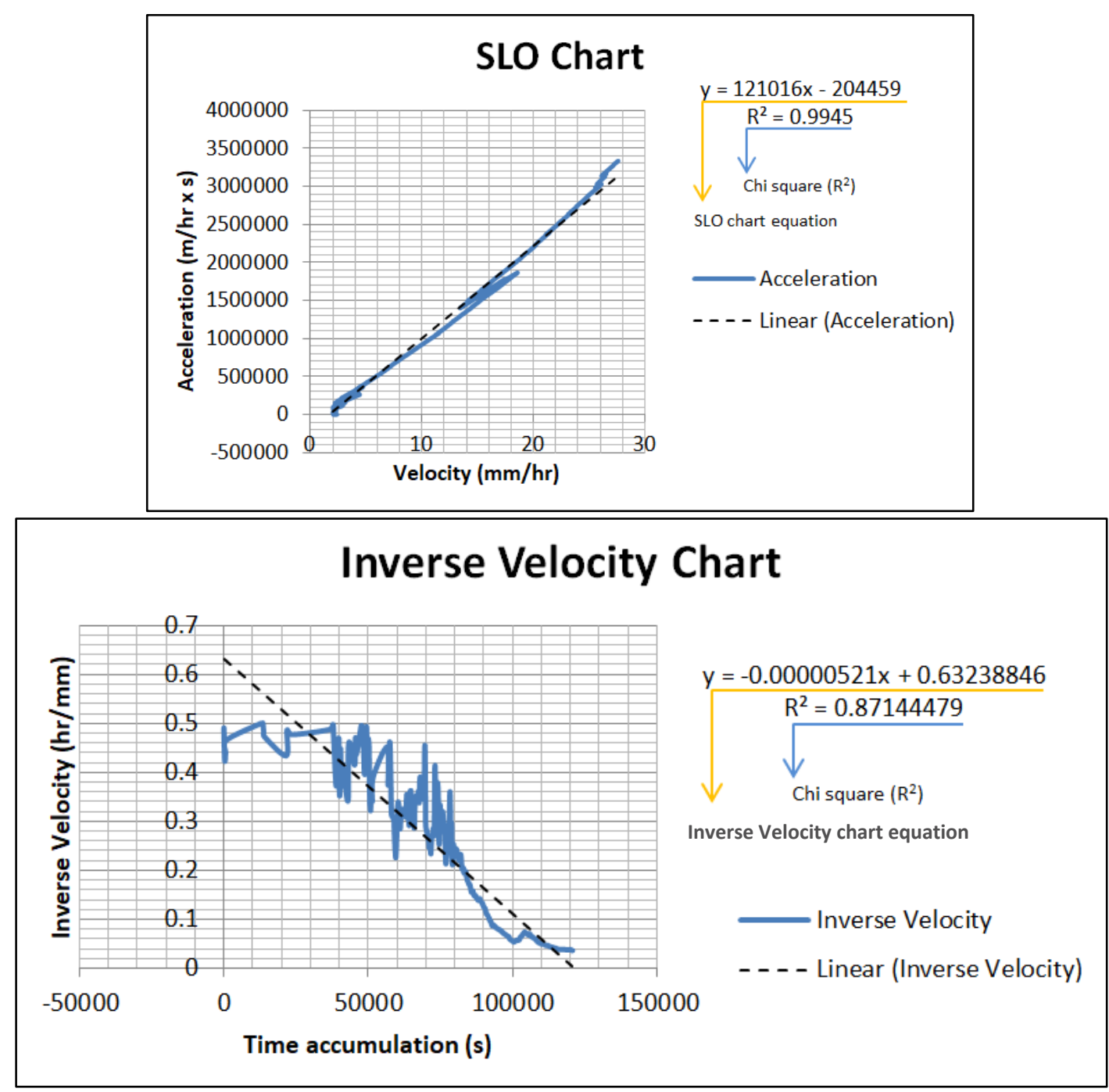

Figure 2. SLO and inverse velocity chart.

In order to generate failure prediction using inverse velocity method, one only needed time accumulation as $\mathrm{X}$ axis and inverse velocity value as $\mathrm{Y}$ axis. Also from the chart, failure prediction can be calculated by using its equation.

3. Compare and analyse the result 
This part is to compare and analyse the result of failure prediction time from both methods. The results from eight sites are compared and analysed with disregard to its geological condition or other external \& internal rock mechanic variable.

\section{DISCUSSION}

The result of SLO \& INV methods to predict failures were presented below. In this paper we use the assumption of velocity \& inverse velocity during the failure event derived from the database of previous failure cases happening on the same area. These values will then be incorporated to the equation of both SLO \& INV method. Simple cross examination calculation subsequently delivers life expectancy of slope wall indicating the timing of failure after nfp 1 (the start of data), or in other words the prediction of time of slope failure. For this paper, the methods were applied to 8 particular mine sites across the globe with different type of geological setting which will not be scrutinized in this occasion.

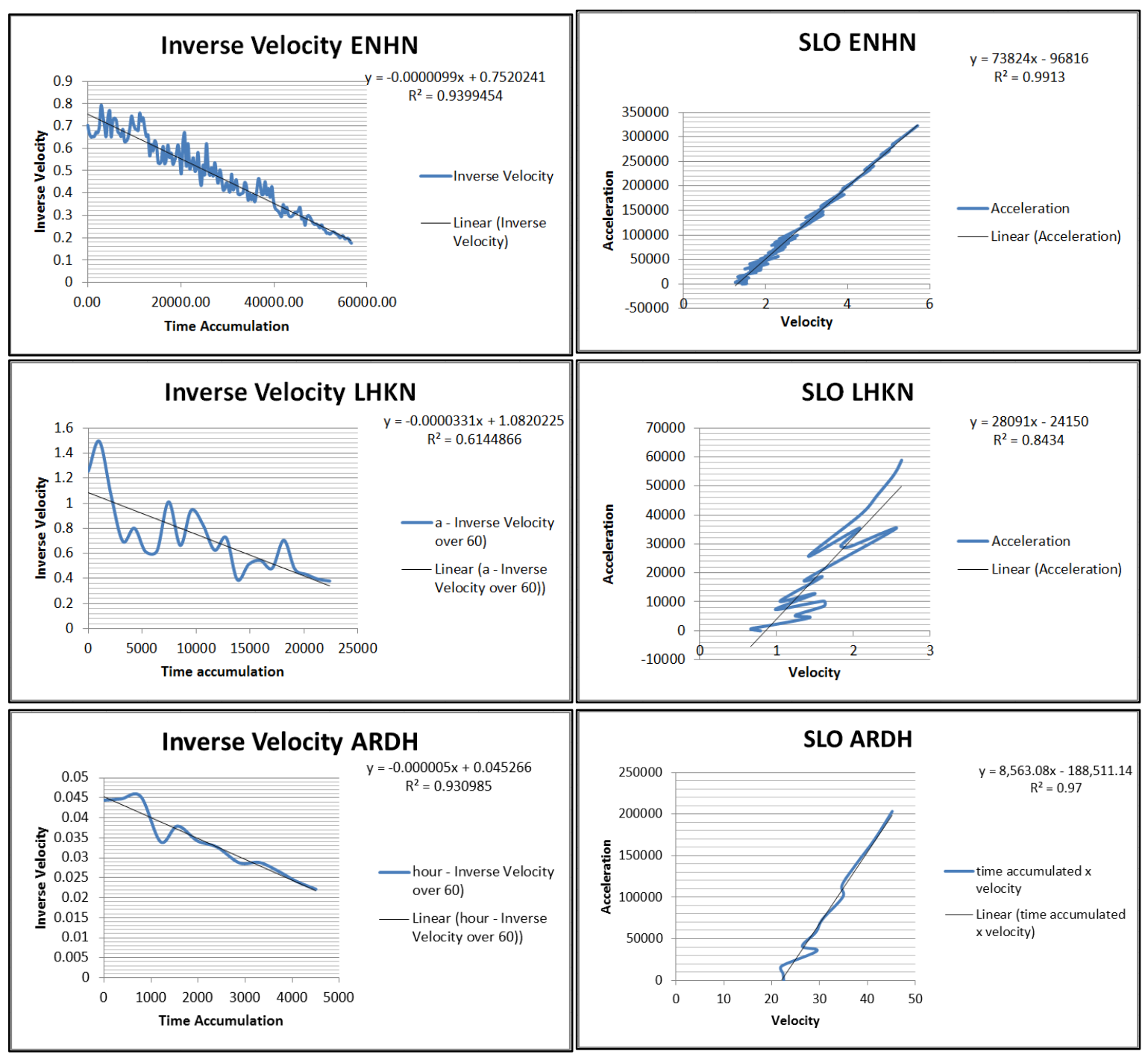




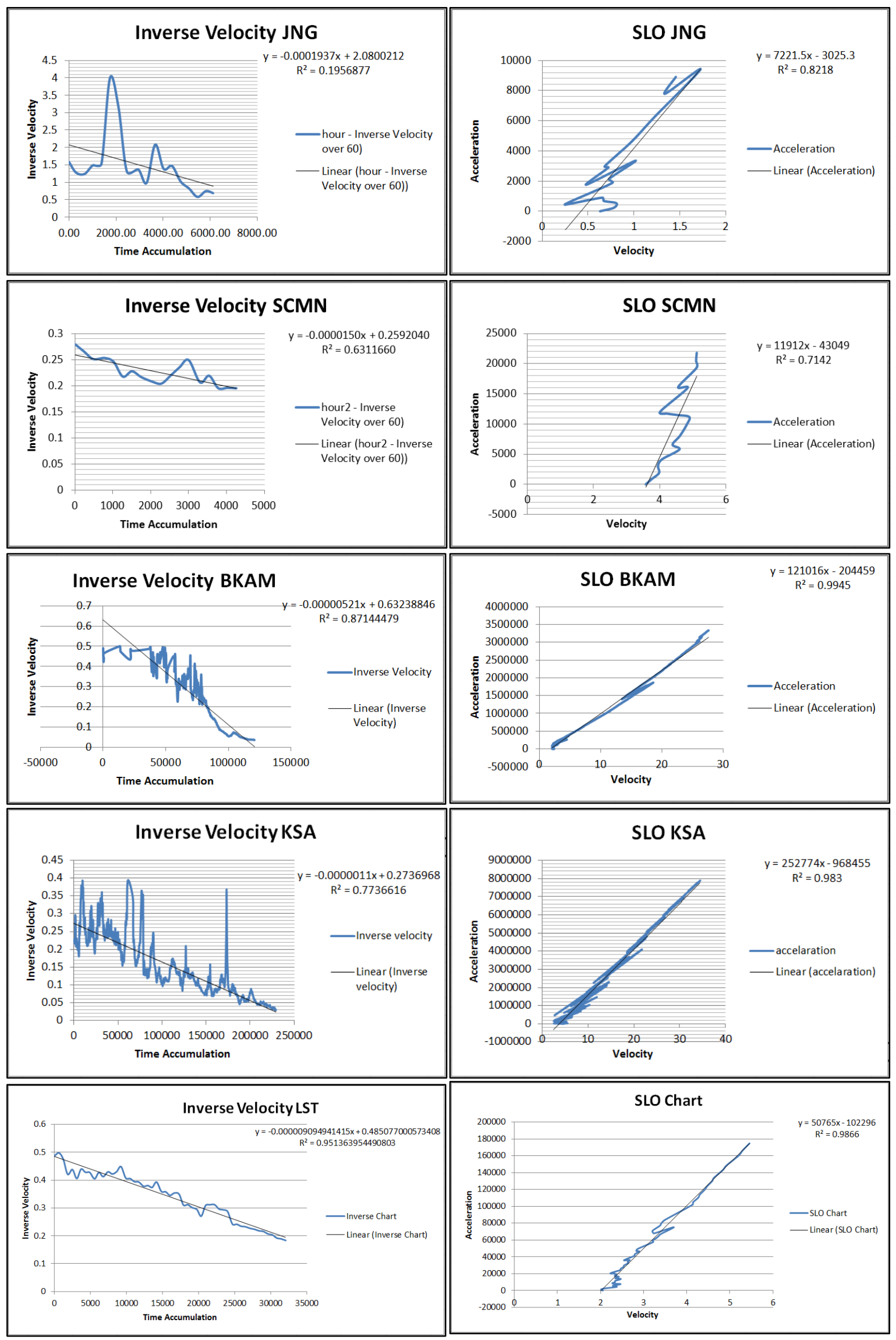

Figure 3. Inverse velocity and SLO chart from eight different sites. 
As mentioned in methodology section, aside from interpretation of its trend, the equation of trend line and chi square is necessary for methodology comparison. Results of calculation using those two methods are presented in Table 1 below.

Table 1. Failure prediction comparison of SLO and inverse velocity calculation method.

\begin{tabular}{|c|c|c|c|c|c|c|c|c|}
\hline \multirow[t]{2}{*}{ No } & \multirow[t]{2}{*}{$\begin{array}{c}\text { Wall } \\
\text { Folder }\end{array}$} & \multicolumn{2}{|c|}{$\mathbf{R}^{2}$} & \multirow[t]{2}{*}{$\begin{array}{l}\text { Actual Time } \\
\text { of Failure }\end{array}$} & \multicolumn{2}{|c|}{ Failure Prediction } & \multicolumn{2}{|c|}{$\begin{array}{c}\text { Time } \\
\text { Discrepancy } \\
\text { (minutes) }\end{array}$} \\
\hline & & INV & SLO & & INV & SLO & INV & SLO \\
\hline 1 & ARDH & 0.93 & 0.97 & 24-11-16 17:58 & 24-11-16 17:01 & $24-11-16 \quad 16: 56$ & -57 & -62 \\
\hline 2 & ENHN & 0.939 & 0.991 & 25-08-08 2:08 & $25-08-082: 32$ & $25-08-08$ 1:56 & +24 & -8 \\
\hline 3 & JNG & 0.19 & 0.82 & 14-03-19 14:06 & $14-03-19$ 14:17 & $14-03-19$ 13:21 & +11 & -45 \\
\hline 4 & LHKN & 0.61 & 0.84 & 24-06-15 6:09 & 24-06-15 5:47 & $24-06-154: 37$ & -22 & -82 \\
\hline 5 & SCMN & 0.63 & 0.71 & $31-01-1621: 59$ & $31-01-16$ 23:07 & $31-01-1621: 49$ & +68 & -10 \\
\hline 6 & BKAM & 0.871 & 0.994 & 25-08-19 11:12 & $25-08-198: 32$ & $25-08-08$ 8:22 & -160 & -170 \\
\hline 7 & KSA & 0.773 & 0.983 & 28-08-19 19:19 & 28-08-19 17:07 & 28-08-19 17:41 & -132 & -98 \\
\hline 8 & LST & 0.951 & 0.987 & $12-06-14$ 11:04 & $12-06-14$ 11:05 & $12-06-14$ 10:27 & +1 & -37 \\
\hline
\end{tabular}

There are three distinguished factor to evaluate which method is the most efficient, those are chi square $\left(\mathrm{R}^{2}\right)$, failure prediction time, and time discrepancy between the failure prediction and the real failure event. Chi square is useful for determine the consistency of data, consistent data value will generate higher value of chi square. As seen from the table, inverse velocity is tend to have small value of $\mathrm{R}^{2}$ which indicate the data of inverse velocity is more inconsistent and more sensitive to noise than SLO data. Failure prediction time can be obtained by using steps explained in methodology section. Most significant factor that can be seen from the table is the time discrepancy results which are obtained from failure prediction time compare to actual time of failure. The highlight is there are 4 failure predictions from inverse velocity method that took place after the real failure event. Meanwhile, from SLO method calculations, all failure predictions happened prior to real failure events.

This result is affected by the fact that inverse velocity calculation is more sensitive to noise as mentioned above. As can be seen on the charts, almost all inverse velocity charts are showing slightly more erratic trend compared to SLO charts. Inverse velocity itself is generated from 1 subdivided by velocity formula so that there is only one attribute which changeable as data acquisition is carried on, that is velocity. Hence, inverse velocity charts would only show stable chart when it is approaching the failure time when the velocity value tend to become more stable. At the same time, if SLO calculation is being breakdown the formula that used in SLO calculation, there are two attributes which may vary depend on their trends, those are velocity and time accumulation. As the velocity value increase, the time accumulation must be accrued from prior data therefore the noise of velocity data will be skewed as accumulation time increased. If it is compared towards chi square $\left(\mathrm{R}^{2}\right)$ values, as another variable of determine data quality, there is also a significant different between these two methods. As we can see from the database, SLO chi square values is more preponderant than inverse method chi square values which corroborate why inverse method charts show more erratic trend. SLO calculation chart shows smoother trend with higher chi square $\left(\mathrm{R}^{2}\right)$ value whilst inverse velocity shows the opposite.

Aside from time discrepancy towards real failure, the easiness to obtain prediction value is also the key. It is about how one can get and where to get. At this point, inverse velocity method has a value added, expectedly due to its status as the most accepted method in geo-mechanic society. In SSR monitoring software, named SSR-Viewer, inverse velocity is one of attribute from velocity tabulation. So, it is very easy to acquire its value just by clicking the critical pixel(s) on deformation image. As discussed on previous methodology part, SLO calculation is attained by 
exporting velocity chart into excel spreadsheet then continued by generating time accumulation vs acceleration diagram chart and calculate the prediction by using chart equation. It clearly denotes that inverse velocity method is way simpler to be generated than the SLO's at least for the moment. Moreover, as another SLO method limitation, previous failure data is a significant attribute to be included to its calculation. Previous failure velocity is used as an assumption that on the same system, it might be a slightly similar velocity value for the rest of failure. If this data is not available then SLO method will border impossibility to be applied. Whereas inverse velocity could always project the value into zero if there is no available inverse velocity value assumption, though as the consequence the likelihood of exceeding the real failure event will increase.

\section{CONCLUSION}

Based on data showed in Table 1, it can be conclude that each method has its own advantage and disadvantage. Inverse velocity method could be beneficial to use if there is not any supporting data from the previous failure. However, inverse velocity can be sensitive towards noise (e.g.; atmospheric changes, riling of loose material, water flow, etc.) which could potentially cause inaccurate failure prediction. Study cases from this paper show that three predictions using inverse velocity method exceed its actual time of failure. Failure prediction using SLO method needs previous failures data to determine its assumed velocity during failure which might be unpractical for some cases. On the other hand, SLO's method has the propensity to yield failure prediction time before the actual failure time, which proved to be useful for any elaborate attempt to address geotechnical instability related hazard.

\section{REFERENCES}

Gunarto E. (2017): Peran IRMS dalam Penyusunan Rancangan Permen Pengelolaan Teknis Pertambangan, Seminar Nasional Geomekanika, P013-015.

Mufundirwa A. (2008): A Study on Prediction of Geomechanical Failure-time and Rock Deformation. A Journal from Division of Solide Waste, Resource, and Geoenviromental Engineering.

Reeves B., Noon D., Stickley G., Longstaff D. (2001): Slope Stability Radar for Monitoring Mine Walls, Proceeding of SPIE vol. 4491 2001, Australia.

Rose N.D., Hungr O. (2007): Forecasting potential rock slope failure in open pit mines using the inverse-velocity method, USA: International Journal of Rock Mechanics \& Mining Sciences $44, \mathrm{P} 308-320$. 